\title{
Centipedes from urban areas in southwestern Siberia, Russia (Chilopoda). Part 1. Lithobiomorpha
}

\section{Губоногие многоножки урбанизированных территорий юга Западной Сибири, Россия (Chilopoda). Часть 1. Lithobiomorpha}

\author{
P.S. Nefediev ${ }^{1}$, I.H. Tuf ${ }^{2} \&$ G.Sh. Farzalieva ${ }^{3}$ \\ П.С. Нефедьев ${ }^{1}$, И.Х. Ту $\phi^{2}$, Г.Ш. Фарзалиева ${ }^{3}$
}

\footnotetext{
${ }^{1}$ Altai State University, Lenin Avenue, 61, Barnaul 656049 Russia. E-mail: p.nefediev@mail.ru

2 Palacký University, Šlechtitelů, 27, Olomouc 77900, Czech Republic. E-mail: ivan.tuf@upol.cz

${ }^{3}$ Perm State University, Bukireva Street, 15, Perm 614600 Russia. E-mail: fgsh@psu.ru

${ }^{1}$ Алтайский государственный университет, проспект Ленина, 61, Барнаул 656049 Россия.

${ }^{3}$ Пермский государственный университет, ул. Букирева, 15, Пермь 614600 Россия.
}

KEY WORDS: Henicopidae, Lithobiidae, anthropochore, faunistics, introduction, Siberia.

КЛЮЧЕВЫЕ СЛОВА: Henicopidae, Lithobiidae, антропохор, фаунистика, интродуцент, Сибирь.

ABSTRACT. The lithobiomorph centipede fauna of urban areas in southwestern Siberia comprises at least eight species from four subgenera, two genera and two families. The following records are new to Russia: Lamyctes (Lamyctes) coeculus (Brölemann, 1889); to the Asian part of Russia: Lithobius (Lithobius) lucifugus L. Koch, 1862; to Siberia: L. (L.) melanops Newport, 1845; or to southwestern Siberia: $L$. (Monotarsobius) crassipes C.L. Koch, 1862, L. (L.) forficatus (Linnaeus, 1758) and Lamyctes (Lamyctes) emarginatus (Newport, 1844). All of the distributions in the region in question are mapped.

РЕЗЮМЕ. Фауна многоножек-костянок урбанизированных территорий юга Западной Сибири включает как минимум восемь видов из четырех подродов, двух родов и двух семейств. Указанные ниже находки оказались новыми для России: Lamyctes (Lamyctes) coeculus (Brölemann, 1889); азиатской части России: Lithobius (Lithobius) lucifugus L. Koch, 1862; Сибири: L. (L.) melanops Newport, 1845; или юга Западной Сибири: L. (Monotarsobius) crassipes C.L. Koch, 1862, L. (L.) forficatus (Linnaeus, 1758) и Lamyctes (Lamyctes) emarginatus (Newport, 1844)). Даны карты с распространением всех видов в указанном регионе.

\section{Introduction}

The fauna of lithobiomorph centipedes of the Asian part of Russia is still very poorly studied [Gerstfeldt, 1858; Stuxberg, 1876; Haase, 1880; Sseliwanoff, 1880, 1881; Zalesskaja, 1978; Vorobiova, 1999; Eason, 1976, 1996; Nefediev, 2001; Rybalov, 2002; Vorobiova et al., 2002; Striganova, Poryadina, 2005; Bukhkalo, Sergeeva, 2012; Sergeeva, 2013]. This is clear even from the present contribution which puts on record several species new to the fauna of Russia, Siberia or southwestern Siberia.

The material treated herein has been deposited mainly in the collection of the Altai State University, Barnaul, Russia (ASU), partly shared also with the collections of the Palacký University, Olomouc, Czech Republic (PUO) and of the Zoological Museum of the Lomonosov Moscow State University, Moscow, Russia (ZMUM), as indicated in the text. Literature references to the species concern the Asian part of Russia only.

Taxonomic part

ORDER LITHOBIOMORPHA

Family Henicopidae

Lamyctes (Lamyctes) coeculus (Brölemann, 1889) Map 1.

MATERIAL EXAMINED. 1 (ASU), Russia, southwestern Siberia, Altai Province, Barnaul, Yuzhnyi, South Siberian Botanical Garden, fern greenhouse, 28.09.-5.12.2013; 1 ㅇ (ZMUM), same locality, flower greenhouse, 28.09.-5.12.2013, all leg. V.M. Mamina.

DISTRIBUTION. The species is distributed cosmopolitically. The Palaearctic realm: Europe (the Canaries, mainland Denmark including Borholm Island, Finland, mainland France, mainland Italy, Sweden including Gotland Island) and the Near East (Asian Turkey, Caucasian Russian republics, Georgia, Armenia, Azerbaijan, Lebanon, Syria, Iran, Iraq, Israel, Jordan, and Sinai Peninsula, Egypt). Also known from the Afrotropical (Arabian Peninsula, Congo, Tanzania, Reunion and Madagascar), Australasian (Australia and Lord 


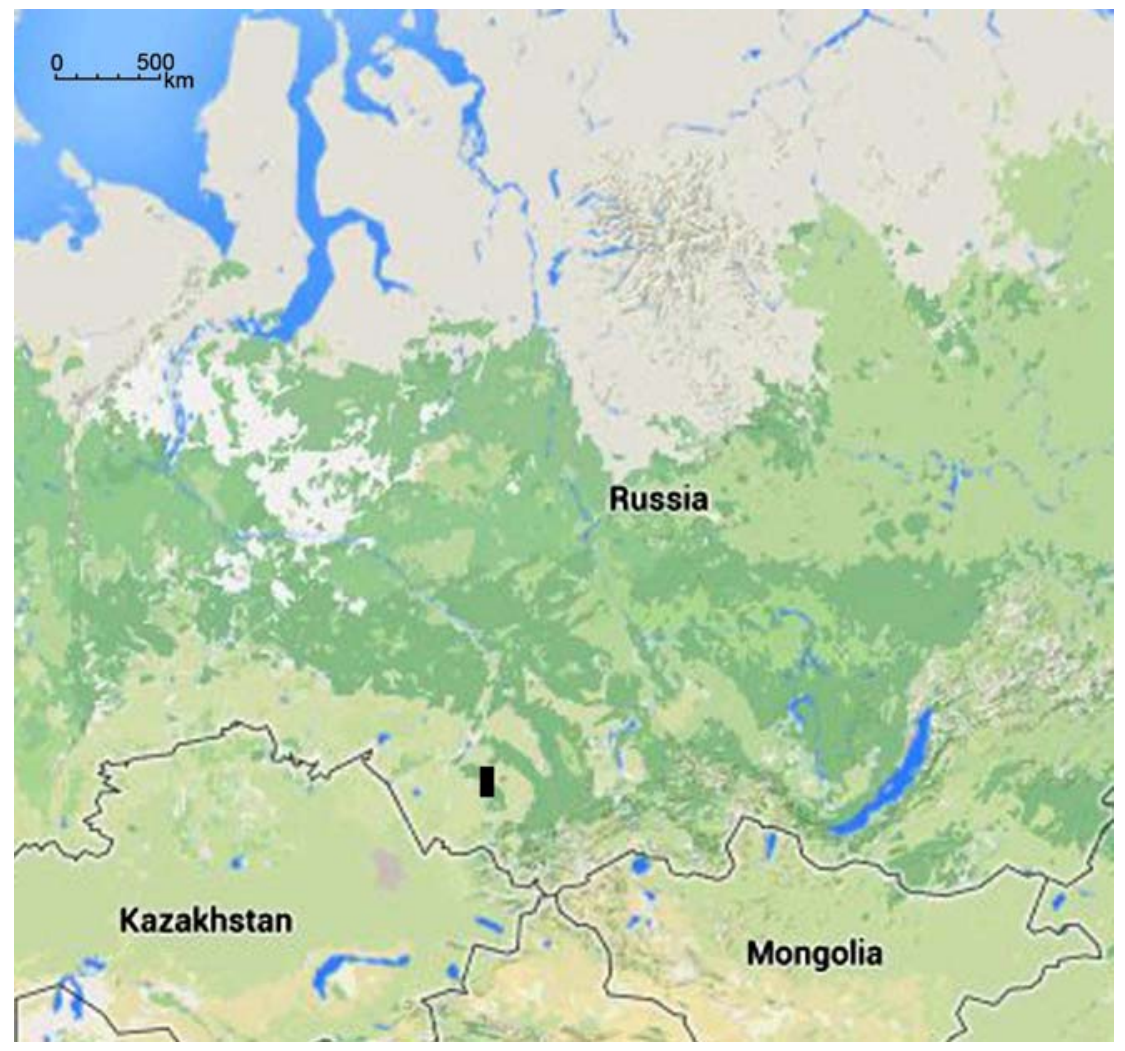

Map 1. Distribution of Lamyctes (Lamyctes) coeculus in Russia (rectangle).

Карта 1. Распространение Lamyctes (Lamyctes) coeculus в России (прямоугольник).

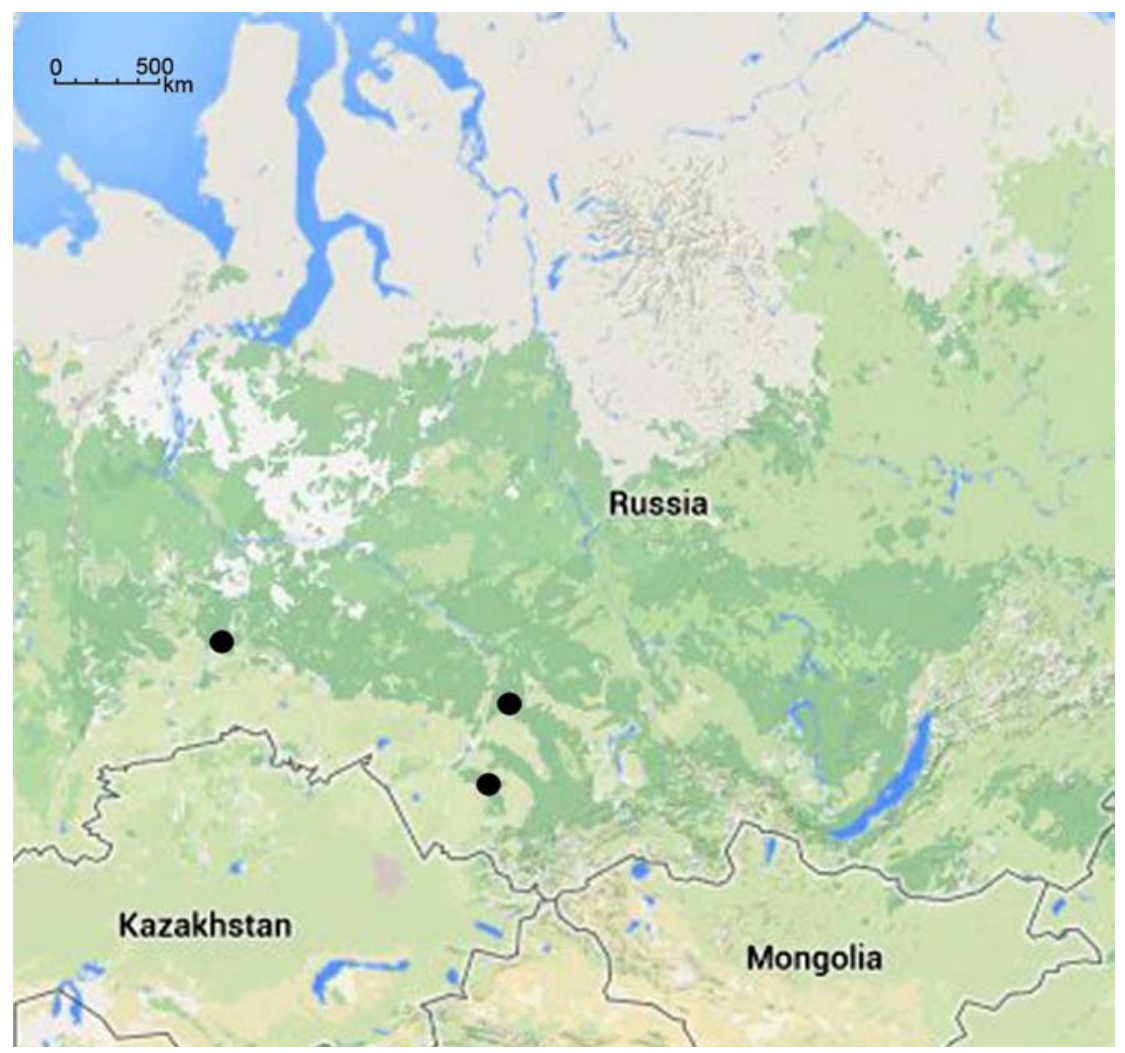

Map 2. Distribution of Lamyctes (Lamyctes) emarginatus in Siberia, Russia (circle). Карта 2. Распространение Lamyctes (Lamyctes) emarginatus в Сибири, Россия (круг). 
Howe Island), Nearctic (Mexico), Neotropical (Mexico, Cuba, Galapagos, Argentina and Venezuela) and Oceania (the Hawaiian Islands) realms [Silvestri, 1909; Enghoff, 1975; Edgecombe, Giribet, 2003; Edgecombe, 2004; Cupul-Magaña, 2011; Zapparoli, 2013; Bonato et al., 2016]. Russia.

REMARKS. This species is new to the fauna of

Lamyctes (Lamyctes) emarginatus (Newport, 1844) Map 2.

Lamyctes fulvicornis Meinert, 1868: Zalesskaja, 1978: 22-24. Lamyctes emarginatus (Newport, 1844): Eason, 1996: 122; Sergeeva, 2013: 530-532.

MATERIAL EXAMINED. 1 (ASU), Russia, southwestern Siberia, Tomsk Area, Tomsk District, Molodjozhnyi, potato field, 8.09.1999, leg. P.S. Nefediev; 1 † (ASU), Russia, southwestern Siberia, Altai Province, Barnaul, Yuzhnyi, South Siberian Botanical Garden, flower greenhouse, 19.06.2013, leg. P.S. Nefediev, Yu.V. Dyachkov; 1 (ASU), same locality, pitfall traps, 13.12.2014, leg. V.M. Mamina; 1 ( ASU), same Province, Pervomaiskii District, Berjozki Railway Station, open hand-made grounds, 20.09.2014, leg. P.S. Nefediev.

DISTRIBUTION. Being indigenous to the Australasian realm, L. (L.) emarginatus was originally described from western and southern Australia including Tasmania, but probably introduced to many oceanic islands of the area, such as New Caledonia, New Zealand, Chatham, Fiji and Kermadec. Presently being cosmopolitan, this species in known from the Palaearctic realm: Europe (Austria, Belgium, Bulgaria, the Canaries, Czech Republic, mainland Denmark including the Faroe Islands and Borholm Island, Finland, mainland France, Germany, Great Britain including the Shetlands, the Orkneys, the Hebrides, and also the Isle of Man, mainland Greece including some islands (Andikithira, Euboea, Samothrace and Thasos) and archipelagos (the Ionian Islands and the Northern Sporades), Iceland, Ireland, mainland Italy including Sardinia, Luxembourg, the Netherlands, Norway, Poland, mainland Portugal including the Azores and Madeira, Romania, Slovakia, Sweden including Gotland Island, Switzerland, Ukraine; probably also present in Liechtenstein); the Near East (Asian Turkey, Caucasian Russian republics, Georgia, Armenia, Azerbaijan, Lebanon, Syria, Iran, Iraq, Israel, Jordan, and Sinai Peninsula, Egypt); northern Africa (Morocco). In Russia, L. (L.) emarginatus is known predominantly from the European part (the republics of Karelia, Mari El, Chuvash and Tatarstan, Ryazan, Moscow, Tula, Ulyanovsk, Samara and Rostov areas, Stavropol Province), also in the Urals (Perm Province, Orenburg and Chelyabinsk areas), and in the Asian part (Tyumen Area, Sakhalin Island and the Kuriles). The Nearctic realm: USA, Mexico, Newfoundland and Greenland. The Neotropical realm: Brazil and the Galapagos Islands. The Afrotropical realm: Arabian Peninsula. The Oceania realm: the Hawaiian Islands [Minoranskij, 1977; Zalesskaja, 1978; Eason, 1996; Farzalieva, 2008; Zapparoli, 2009, 2013; Cupul-Magaña, 2013; Ser- geeva, 2013; Volkova, 2014a; Zuev, 2016; Bonato et al., 2016].

REMARKS. This species has hitherto been recorded neither in the Tomsk Area nor in the Altai Province, southwestern Siberia.

\section{Family LITHOBIIDAE} 1862

Lithobius (Monotarsobius) crassipes C.L. Koch, Map 3. 531

Lithobius crassipes C.L. Koch, 1862: Sergeeva, 2013: 530-

MATERIAL EXAMINED, $1 \sigma^{7}, 19$ (ASU), Russia, southwestern Siberia, Altai Province, Barnaul, Kirova, Pinus sylvestris, 21.06.2012, leg. Yu.V. Dyachkov; 1 \% (PUO), same Province, Barnaul, Yuzhnyi, South Siberian Botanical Garden, flower greenhouse, 28.09.-5.12.2013; 1 ㅇ (PUO), same locality, exotic greenhouse, 28.09.2013, all leg. V.M. Mamina; $4 \sigma^{7} \sigma^{7}, 5$ 90 (ASU), same Province, Barnaul, "Lesnaya Skazka" Park, Acer and Betula, under boards, stones, in litter, 1.05.2015; 1 \% (ASU), same Province, Barnaul, Betula, Acer, 11.04.2016; 1 \%, 7 우 (ASU), Russia, same Province, Biysk, LLC "Sibenergosnab", cucumber greenhouse, 16.03.2010, all leg. P.S. Nefediev.

DISTRIBUTION. Being a western Palaearctic species, L. (M.) crassipes is widespread in the Palaearctic realm: Europe (Albania, Austria, Belgium, Bosnia and Herzegovina, Bulgaria, the Canaries, Croatia, Czech Republic, mainland Denmark including Borholm Island, Finland, mainland France, Germany, Great Britain including the Shetlands, the Orkneys, the Hebrides, and also the Isle of Man, mainland Greece including some islands (Andikithira, Crete, Euboea, Samothrace and Thasos) and archipelagos (the Dodecanese, the Ionian Islands and the Northern Sporades), Hungary, Ireland, mainland Italy including Sardinia and Sicily, Luxembourg, Macedonia, Madeira, the Netherlands, mainland Norway, Poland, Romania, Slovakia, Slovenia, mainland Spain including Alboran Island, Sweden including Gotland Island, Switzerland, European Turkey including Imroz Island, Ukraine; doubtfully present in Liechtenstein and Northern Ireland), northern Africa (Algeria and Tunisia) and the Near East (Asian Turkey, Caucasian Russian republics, Georgia, Armenia, Azerbaijan, Lebanon, Syria, Iran, Iraq, Israel, Jordan, and Sinai Peninsula, Egypt). In the European part of Russia, it has been found in the Moscow, Ulyanovsk and Rostov-on-Don areas, the republics of Karelia, Adygea, Komi and Crimea, the Krasnodar, Perm and Stavropol provinces and the Nenets Autonomous Region in the Arkhangelsk Area (Vaygach Island), while in Asian Russia in the Krasnoyarsk Province (Vorogovo and Nizhne-Imbatsk) and the Tyumen Area. Also known from the Afrotropical (Arabian Peninsula), IndoMalayan (Taiwan) and Nearctic (USA) realms [Minoranskij, 1977; Zalesskaja, 1978; Farzalieva, 2008; Zapparoli, 2009, 2011; Sergeeva, 2013; Volkova, 2014a; Zuev, 2016].

REMARKS. This species has hitherto never been recorded in the Altai Province, southwestern Siberia. 


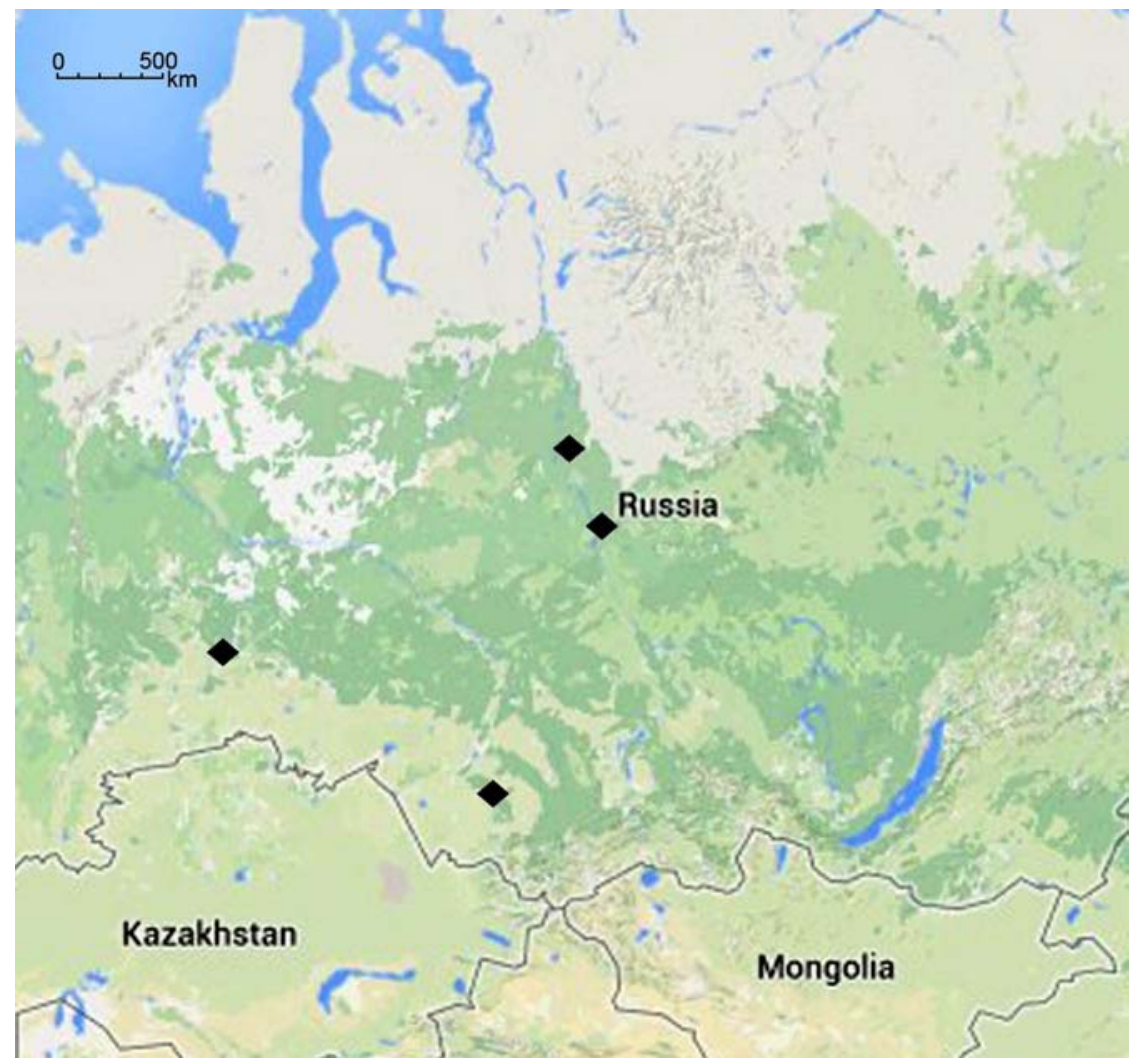

Map 3. Distribution of Lithobius (Monotarsobius) crassipes in Siberia, Russia (diamond). Карта 3. Распространение Lithobius (Monotarsobius) crassipes в Сибири, Россия (ромб).

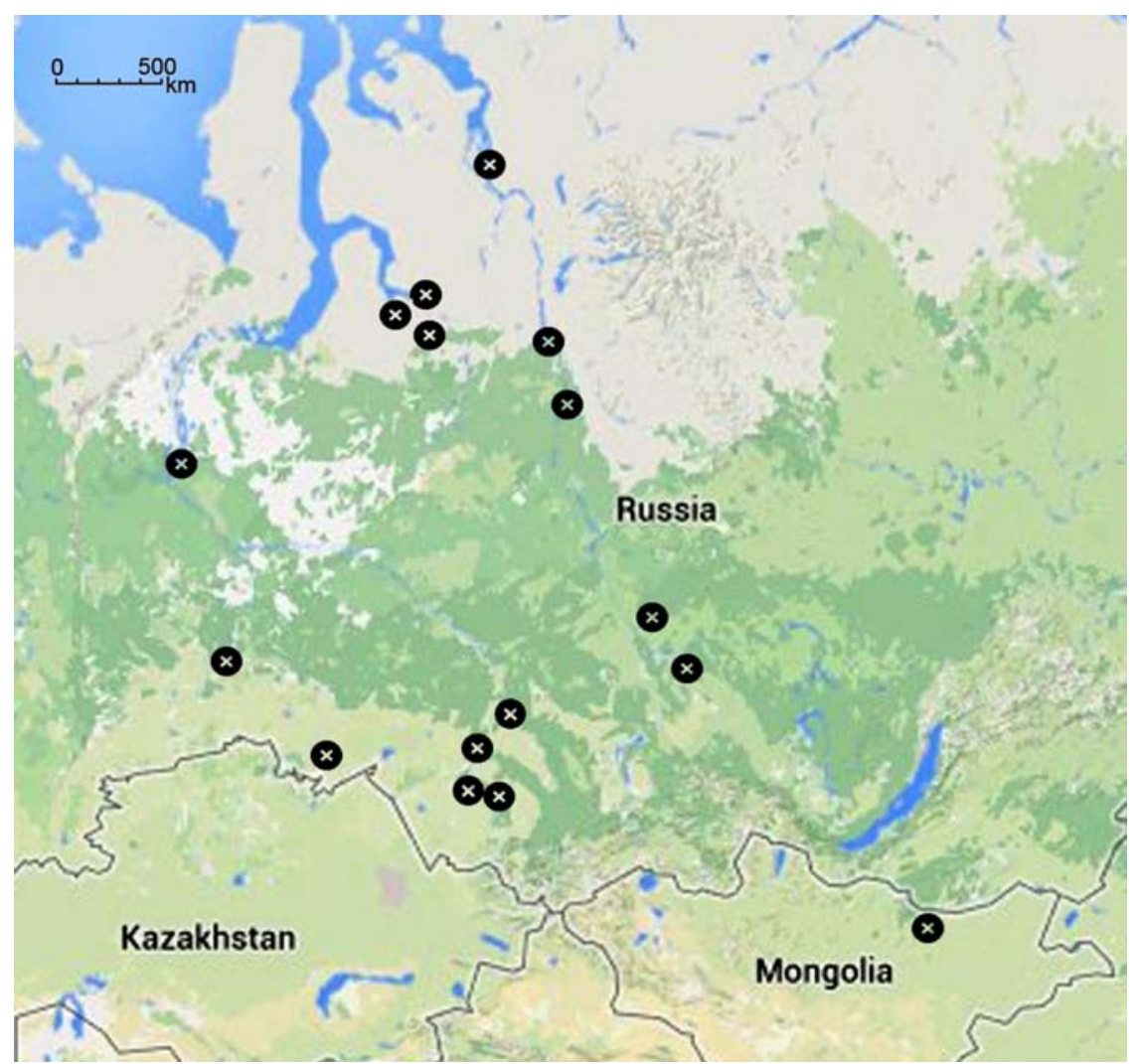

Map 4. Distribution of Lithobius (Monotarsobius) curtipes in Siberia, Russia and Mongolia (crossed circle). Карта 4. Распространение Lithobius (Monotarsobius) curtipes в Сибири, Россия и Монголии (крест в круге). 


\section{Lithobius (Monotarsobius) curtipes C.L. Koch, 1847 Map 4.}

Lithobius curtipes C.L. Koch, 1847: Vorobiova, 1999: 33-34; Vorobiova et al., 2002: 61; Striganova, Poryadina, 2005: 226; Bukhkalo, Sergeeva, 2012: 61; Sergeeva, 2013: 530-532.

MATERIAL EXAMINED. 3 ○' $\sigma^{7}, 1$ ( (ASU), Russia, southwestern Siberia, Altai Province, Pervomaiskii District, Bobrovka, Pinus sylvestris, 20.08.1999; $2 \sigma^{\top} \sigma^{\top}, 2$ (ASU), Russia, same Province, Kamenskii District, Kamen-na-Obi, right bank of $\mathrm{Ob}$ River, Betula and Populus tremula, 23.08.2000; $1 \Im^{\top}, 2$ 우 (ASU), same locality, Betula, in litter, 24.08.2000, all leg. A.V. Udaloj; 2 † (ASU), same Province, Barnaul, Nauchnyi Gorodok, 11.08.2005, leg. A.S. Babenko; $1 \sigma^{\top}$ (ASU), Russia, same Province, Barnaul, "Nagornyi" Park, pitfall traps, 13-23.06.2014; 1 \% (ASU), same Province, Barnaul, "Izumrudnyi" Park, Acer, Populus, June 2014 all leg. A.A. Streltsova; $1 \sigma^{\top}$ (ASU), Russia, southwestern Siberia, Tomsk Area, ca. $10 \mathrm{~km} \mathrm{~N}$ of Tomsk, "Tomskneftekhim", near Acetylene Plant, Populus tremula, 4.05.2003, leg. P.S. Nefediev.

DISTRIBUTION. A Central Asian-European species widespread mainly in the Palaearctic realm: Europe (Belarus, Belgium, Bulgaria, Czech Republic, mainland Denmark including Borholm Island, Finland, mainland France, Germany, Great Britain including the Shetlands, the Orkneys, the Hebrides, and also the Isle of Man, Hungary, Lithuania, Luxembourg, Moldova, the Netherlands, mainland Norway, Poland, Romania, Slovakia, Sweden including Gotland Island, Switzerland, Ukraine), the Near East (Asian Turkey, Caucasian Russian republics, Georgia, Armenia, Azerbaijan, Lebanon, Syria, Iran, Iraq, Israel, Jordan, and Sinai Peninsula, Egypt) and the East Palaearctic (Mongolia). In European Russia, L. (M.) curtipes is known from the Arkhangelsk, Kaluga, Kursk, Moscow, Murmansk, Rostov-on-Don, Samara, Ulyanovsk, Vladimir, Volgograd, Voronezh and Yaroslavl areas, the Krasnodar and Stavropol provinces, the republics of Bashkortostan, Chuvash, Komi, Mari El, Mordovia and Tatarstan, also from the Urals (Perm Province, Orenburg, Chelyabinsk and Sverdlovsk areas), in Siberia from the Novosibirsk and Tyumen areas, the Krasnoyarsk Province and Altai. Also known from the Afrotropical realm: Arabian Peninsula [Minoranskij, 1977; Zalesskaja, 1978; Vorobiova, 1999; Rybalov, 2002; Vorobiova et al., 2002; Striganova, Poryadina, 2005; Farzalieva, 2008; Bukhkalo, Sergeeva, 2012; Sergeeva, 2013; Zapparoli, 2013; Volkova, 2014a; Tuf et al., 2015; Zuev, 2016; Poloczek et al., 2016; Korobushkin et al., 2016].

REMARKS. Northern Mongolia is the easternmost range limit of L. (M.) curtipes [Poloczek et al., 2016].

\section{Lithobius (Lithobius) forficatus (Linnaeus, 1758) Map 5.}

Lithobius forficatus (Linnaeus, 1758): Eason, 1996: 118; Sergeeva, 2013: 530-532.

MATERIAL EXAMINED. $1 \sigma^{7}, 1$ (ASU), Russia, southwestern Siberia, Tomsk Area, Tomsk, Siberian Botanical Garden, hothouses, 10.12.1999; 3 ㅇ (ASU), same locality, 3.03.2000; 5 $\sigma^{\top} \sigma^{\top}, 4$ 우, 2 juv. (ASU), same locality, 21.04.2000; 1 +, 3 juv., 1 fragm. (ASU), same locality, 19.12.2000; 1 (ASU), same Area, Tomsk, Zavarzino, floodplain of Ushaika River, 1.09.2002, all leg P.S. Nefediev; $1 \sigma^{\top}, 1$ (ASU), same locality, south hothouse, pitfall traps, 28.03.-14.04.2006; $1 \sigma^{7}$ (ASU), same locality, hot- house with pond, pitfall traps, 28.03.-14.04.2006; 1 \% (ASU), same locality, coniferous hothouse, pitfall traps, 29.03.-14.04.2006; $4 \bigcirc^{7} \sigma^{7}, 3$ ơ (ASU), same locality, rose hothouse, pitfall traps, 28.03-14.04.2006, all leg. P.S. Nefediev, A.M. Folin; $1 \sigma^{7}$ (ASU), same Area, Tomsk, Ushaika River in city centre, on road, 14.06.2001; 1 q (ASU), same Area, Tomsk, Universitetskaya Roshcha, 19.04.2000, all leg. P.S. Nefediev; $2 \sigma^{\top} \sigma^{7}, 3$ 우 (ASU), same locality, 10-22.07.2000, leg. Rudenko; 1 ๙ , 1 \% (ASU), Russia, same Area, Tomsk, experimental plot of Botany Department of Tomsk Agricultural Institute, open hand-made grounds, 26.05.2005, leg. E.V. Miroshnichenko; 3 0 ( (ASU), same Area, Tomsk, near Avangard, meadow in Betula forest, 26.05.2005; 3 of (ASU), same Area, Tomsk, "Buff-Sad" Park, Acer and Populus, 15.05.2008, 1 (ASU), same Area, Tomsk, small square of Betula in Kashtak, 16.05.2008, all leg. P.S. Nefediev; $3 \sigma^{7} \sigma^{7}, 4$ Oᄋ (ASU), Russia, southwestern Siberia, Altai Province, Biysk, Sorokino, right bank of Biya River, Malus, litter, 11.10.2009; 1 \% , 1 ( ASU), same locality, Populus, under felled tree trunks and under barks, 19.10.2009; 3 우 (ASU), same locality, Populus stands, 20.10.2009; 19 (ASU), same Province, Biysk, LLC "Sibenergosnab", cucum-

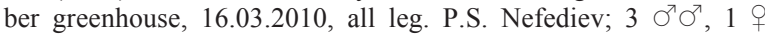
(ASU), same Province, Barnaul, Kirova, Pinus sylvestris, 21.06. 2012; $1 \sigma^{7}, 1$ (ASU), Russia, southwestern Siberia, Altai Province, Barnaul, "Izumrudnyi" Park, 20.06.2012, all leg. Yu.V. Dyachkov; $5 \sigma^{7} \sigma^{7}, 3$ 90 (ASU), same locality, Populus, summer 2013, leg. V.M. Mamina; 2 우 (ASU), same locality, June 2014; 1 $\sigma^{\top}, 5$ 우 (ASU), same Province, Barnaul, "Yubileinyi" Park, July 2014, all leg. A.A. Streltsova; $2 \sigma^{7} \sigma^{\top}, 4$ juv. (ASU), same Province, Barnaul, "Edelveis" Park, summer 2013, leg. V.M. Mamina; $6 \sigma^{7} \sigma^{7}$ 4 우, 2 juv. (ASU), same Province, Barnaul, "Lesnaya Skazka” Park, Acer and Betula, under boards, stones, in litter, 1.05.2015; 2 우, 1 juv. (ASU), same Province, Barnaul, Betula, Acer, 11.04.2016, all leg. P.S. Nefediev; $1 \Im^{7}, 1$ (ASU), same Province, Barnaul, Borzovaya Zaimka, summer 2013; 1 o , 1 (ASU), same Province, Barnaul, Vlasikha, kitchen-garden, summer 2013, all leg. V.M. Mamina; $1 \sigma^{\top}, 2$ + 2 (PUO), Russia, southwestern Siberia, Altai Province, Barnaul, Yuzhnyi, South Siberian Botanical Garden, open handmade grounds, 19.06.2013; $1 \sigma^{7}$ (ASU), same locality, flower greenhouse, 19.06.2013, all leg. P.S. Nefediev, Yu.V. Dyachkov; $1 \sigma^{7}, 19$ (ASU), same Province, Barnaul, M.A. Lisavenko Research Institute for Horticulture of Siberia, Quercus grove, 23.06.2012, leg. Yu.V. Dyachkov; $9 \sigma^{7} \sigma^{\top}, 5$ 0 , 1 juv. (ASU), same locality, heated hothouse, 16.06.2015; 1 \% (ASU), same locality, summer hothouse, 16.06.2015; $1 \sigma^{7}, 1$ (ASU), Russia, southwestern Siberia, Altai Province, Pervomaiskii District, Berjozki Railway Station, open hand-made grounds, 7.06.2014; $2 \sigma^{\top} \sigma^{\top}$ (ASU), same locality, 15.06.2014; 5 O $^{7}$ (ASU), same locality, 20.09.2014; 2 우 (ASU), same locality, 11.05.2015; $1 \sigma^{7}$ (ASU), same locality, 25.05.2014, all leg. P.S. Nefediev; 1 \%, 1 juv. (ASU), same Province, Blagoveschenka District, Glyaden, Acer and Betula woodland belt, 1014.08.2014, leg. A. Polyakov; $2 \sigma^{\top} \sigma^{\top}$ (ASU), same Province, Romanovo District, Tambovskii, 19.08.2015, leg. I.K. Tyutyunnik.

DISTRIBUTION. Being apparently indigenous to Europe, $L$. (L.) forficatus is highly widespread all over the world. In the Palaearctic realm, it inhabits Europe (Albania, Austria, Belarus, Belgium, Bosnia and Herzegovina, Bulgaria, Croatia, Czech Republic, mainland Denmark including the Faroe Islands and Borholm Island, Finland, mainland France including Corsica, Germany, Great Britain including the Shetlands, the Orkneys, the Hebrides, the Channel Islands and also the Isle of Man, mainland Greece including some islands (Andikithira, Euboea, Samothrace and Thasos) and archipelagos (the Ionian Islands and the Northern Sporades), Hungary, Iceland, Ireland, mainland Italy including Sardinia and Sicily, Lithuania, Luxembourg, Macedonia, Malta, Moldova, Montenegro, the Netherlands, mainland Norway, Poland, Romania, Serbia including Kosovo and Voivodina, Slovakia, Slovenia, 


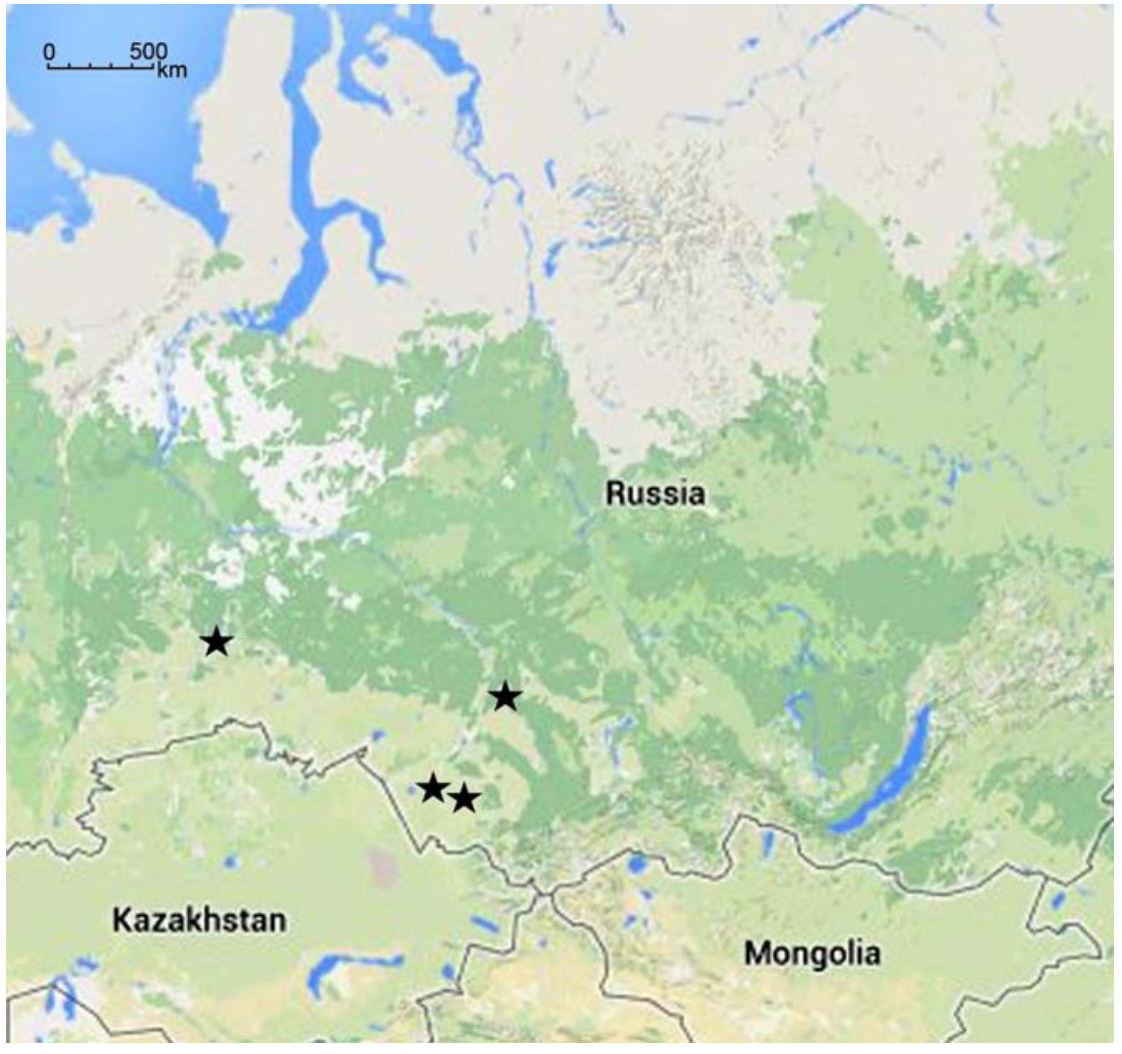

Map 5. Distribution of Lithobius (Lithobius) forficatus in Siberia, Russia (asterisk).

Карта 5. Распространение Lithobius (Lithobius) forficatus в Сибири, Россия (звезда).

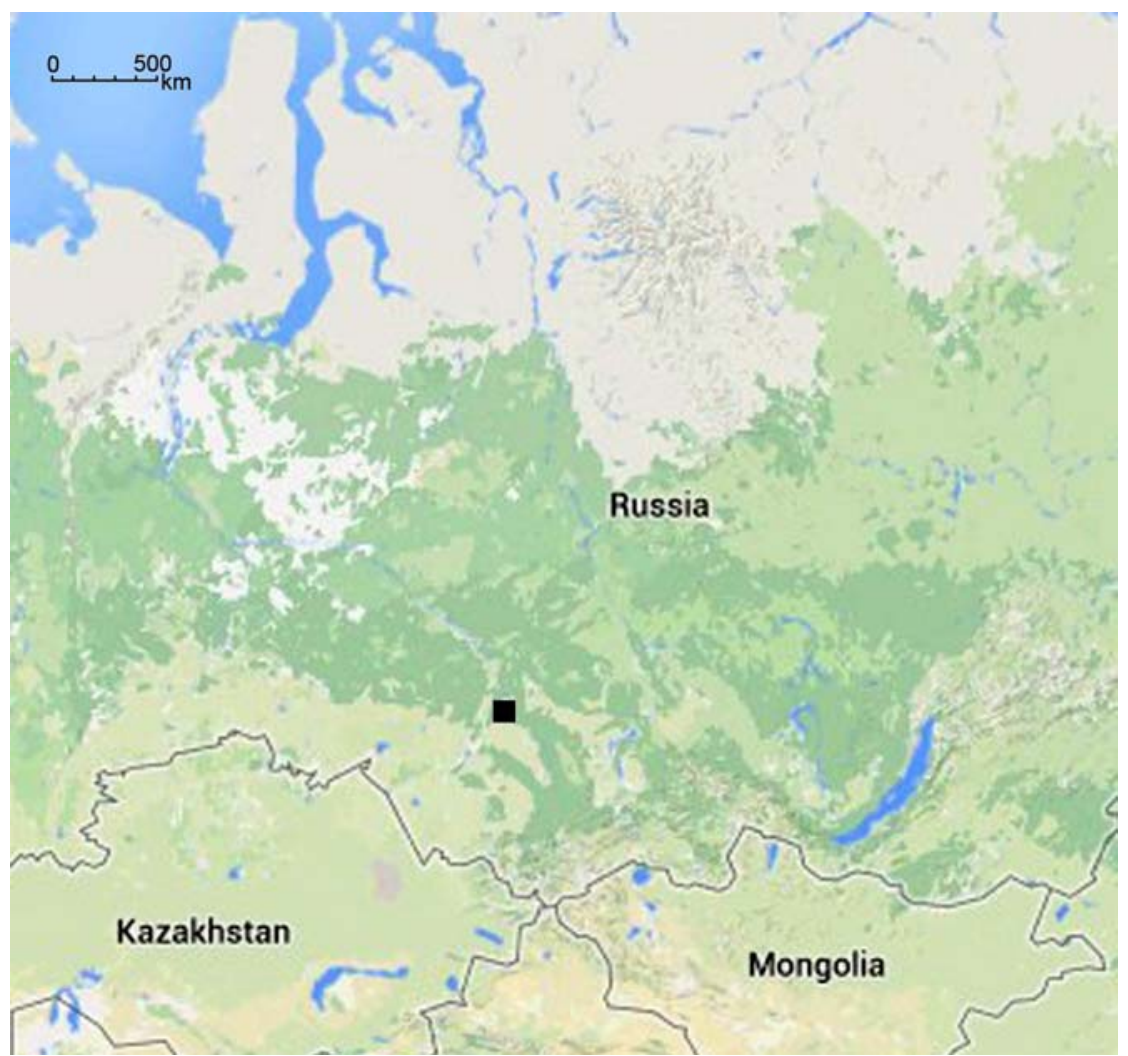

Map 6. Distribution of Lithobius (Lithobius) lucifugus in Asian Russia (square).

Карта 6. Распространение Lithobius (Lithobius) lucifugus в азиатской России (квадрат). 
mainland Spain including Alboran Island, Sweden including Gotland Island, Switzerland, European Turkey including Imroz Island, Ukraine; probably present also in Liechtenstein, Northern Ireland and San Marino), the Near East (Asian Turkey, Caucasian Russian republics, Georgia, Armenia, Azerbaijan, Lebanon, Syria, Iran, Iraq, Israel, Jordan, and Sinai Peninsula, Egypt) and the East Palaearctic (Mongolia); in the European part of Russia it occurs in the republics of Karelia, Mari El, Tatarstan, Chuvash and Crimea, the Leningrad, Ryazan, Tver, Oryol, Moscow, Yaroslavl, Kaluga, Kursk, Rostov-on-Don, Sverdlovsk, Ulyanovsk and Voronezh areas, the Perm and Krasnodar provinces, but in the Asian part of Russia it is only known from the Tyumen Area and Iturup Island, Kuriles. Also introduced to the Afrotropical, Neotropical (Brazil), Nearctic (North America and Greenland), and Australasian realms (Australia and New Zealand) [Minoranskij, 1977; Zalesskaja, 1978; Eason, 1996; Zapparoli, 2003, 2013; Farzalieva, 2008; Sergeeva, 2013; Volkova, 2014a; Tuf et al., 2015; Korobushkin et al., 2016].

REMARKS. This species has hitherto been recorded neither in the Tomsk Area nor in the Altai Province, southwestern Siberia.

\section{Lithobius (Lithobius) lucifugus L. Koch, 1862 Map 6.}

MATERIAL EXAMINED. 1 (ASU), Russia, southwestern Siberia, Tomsk Area, Tomsk, Siberian Botanical Garden, hothouses, 19.12.2000, leg. P.S. Nefediev.

DISTRIBUTION. A Central European species widespread in the Palaearctic realm: Europe (Albania, Austria, Belarus, Bulgaria, Croatia, Czech Republic, mainland France, Germany, Hungary, mainland Italy including Sardinia, Latvia, Moldova, Montenegro, Romania, Serbia including Kosovo and Voivodina, Slovakia, Slovenia, Sweden including Gotland Island and Gotska Sandön Island, Switzerland, European Turkey including Imroz Island, Ukraine; probably present also in Liechtenstein, Crete and mainland Portugal), the Near East (Asian Turkey, Caucasian Russian republics, Georgia, Armenia, Azerbaijan, Lebanon, Syria, Iran, Iraq, Israel, Jordan, and Sinai Peninsula, Egypt). In Russia, it occurs, within the European part, in the republics of Mari El, Tatarstan, Chuvash and Crimea, the Moscow, Ryazan, Saratov, Samara, Kursk, Orenburg, Chelyabinsk and Ulyanovsk areas and the Perm Province [Zalesskaja, 1978; Tuf, Laška, 2005; Farzalieva, 2008; Zapparoli, 2009, 2013; Volkova, 2014a, b; Tuf et al., 2015].

REMARKS. Lithobius (Lithobius) lucifugus is new to Asian Russia. This species frequently inhabits subterranean environment including artificial ones [Dvořák, Dvořáková, 2015; Tuf et al., in press].

\section{Lithobius (Lithobius) melanops Newport, 1845 Map 7.}

Lithobius melanops Newport, 1845: Eason, 1996: 118.
MATERIAL EXAMINED. $1 \bigcirc^{7}$ (ASU), Russia, southwestern Siberia, Tomsk Area, Tomsk, Universitetskaya Roshcha, Betula, 29-30.05.2005; 1 \& (ASU), Russia, southwestern Siberia, Altai Province, Pervomaiskii District, Beryozki Railway Station, open hand-made grounds, 15.06.2014, all leg. P.S. Nefediev.

DISTRIBUTION. A European species widespread in the Palaearctic realm: Europe (Austria, the Azores, Belgium, Bosnia and Herzegovina, the Canaries, Croatia, Czech Republic, mainland Denmark including the Faroe Islands and Borholm Island, Finland, mainland France, Germany, Great Britain including the Shetlands, the Orkneys, the Hebrides, and also the Isle of Man, Hungary, Iceland, Ireland, mainland Italy including Sardinia, Latvia, Lithuania, Luxembourg, Madeira, the Netherlands, mainland Norway, Poland, Romania, Slovakia, Slovenia, mainland Spain including Alboran Island, Sweden including Gotland Island and Gotska Sandön Island, Switzerland, Ukraine; probably present also in Liechtenstein) and northern Africa. In Russia, it occurs, within the European part, in the Republic of Karelia, the Moscow and Ulyanovsk areas and the Stavropol Province, also from the Kuriles (Iturup, Shikotan and Zeljonyi islands); introduced to the Nearctic (USA) as well as Neotropical (the Falkland Islands) realms [Zalesskaja, 1978; Eason, 1977, 1996; Tuf, Laška, 2005; Zapparoli, 2009, 2013; Barber, 2011; Volkova, 2014a; Tuf et al., 2015; Zuev, 2016].

REMARKS. This species is new to the fauna of Siberia, Russia. It is strongly synanthropic, frequently inhabiting buildings and greenhouses [e.g. Lewis, 1975; Eason, 1977; Barber, 2011].

\section{Lithobius (Ezembius) sibiricus Gerstfeldt, 1858 Map 8.}

Lithobius sibiricus Gerstfeldt, 1858: 275-276; Stuxberg, 1876: 11; Haase, 1880: 223-224; Nefediev, 2001: 85; Vorobiova, 1999: 33-34; Vorobiova et al., 2002: 62.

Lithobius (Ezembius) sibiricus Gerstfeldt, 1858: Zalesskaja, 1978: 224-225; Poloczek et al., 2016: 117.

MATERIAL EXAMINED. $1 \sigma^{\top}$ (ASU), Russia, southwestern Siberia, Tomsk Area, Tomsk District, Kaftanchikovo, Populus tremula, Betula, 25.09.2002; 9 O $^{\top}$ (ASU), same Area, ca. $10 \mathrm{~km}$ N of Tomsk, "Tomskneftekhim", near Acetylene Plant, Populus tremula, 4.05.2003; $2 \sigma^{7} \sigma^{7}$ (ASU), same Area, Tomsk, "Lagernyi

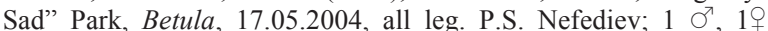
(ASU), Russia, southwestern Siberia, Altai Province, Barnaul, Nauchnyi Gorodok, 11.08.2005, leg. A.S. Babenko; 1 \%, 2 우 (ASU), same Province, Barnaul, Kirova, Pinus sylvestris, 21.06.2012, leg. Yu.V. Dyachkov; $7 \sigma^{7} \sigma^{7}, 2$ o, 1 juv. (ASU), same Province, Smolenskoe District, Smolenskoe, Poperechnaya River, Populus, 21.04.2013, leg. P.S. Nefediev, Yu.S. Nefedieva.

DISTRIBUTION. Being one of the most widespread species in Siberia, Russia, L. (E.) sibiricus is only known from the Asian subregion of the Palaearctic: Asian Russia in Western, Central and Eastern Siberia (Tomsk Area, Altai Province, Krasnoyarsk Province, Irkutsk Area, Zabaikalskii Province and the republics of Buryatia and Sakha), the Russian Far East (Amur Area, Maritime Province and Sakhalin Island) and northern Mongolia [Gerstfeldt, 1858; Zalesskaja, 1978; Nefediev, 2001; Vorobiova, 1999; Vorobiova et al., 2002; Poloczek et al., 2016]. 


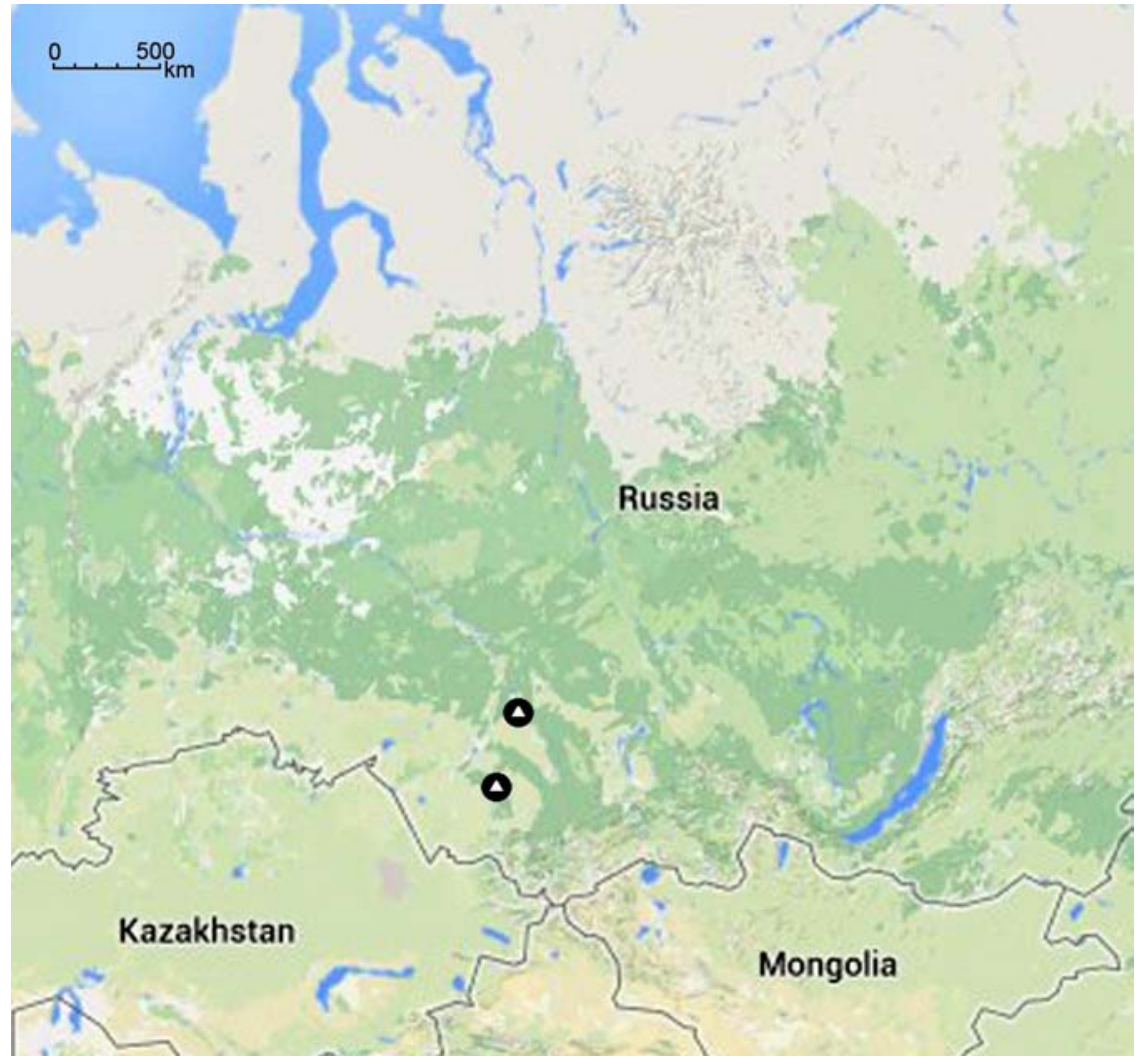

Map 7. Distribution of Lithobius (Lithobius) melanops in Siberia, Russia (triangle inside circle).

Карта 7. Распространение Lithobius (Lithobius) melanops в Сибири, Россия (треугольник в круге).

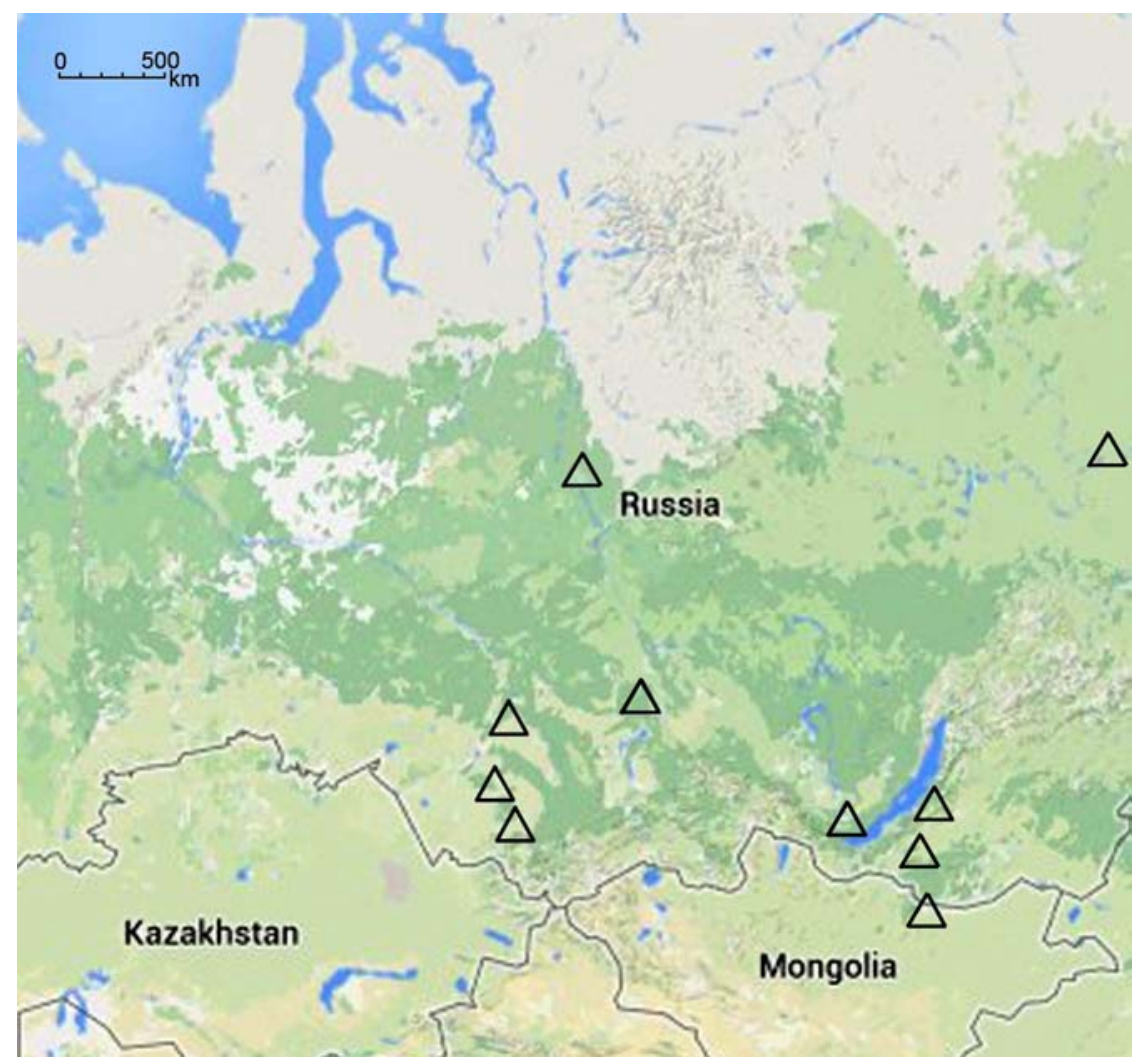

Map 8. Distribution of Lithobius (Ezembius) sibiricus in southwestern Siberia, Russia and Mongolia (empty triangle).

Карта 8. Распространение Lithobius (Ezembius) sibiricus на юге Западной Сибири, Россия и Монголии (прозрачный треугольник). 


\section{Conclusions}

At present, at least eight species from four subgenera, two genera and two families of Lithobiomorpha are known to occur in urban areas in southwestern Siberia, Russia. Lamyctes (Lamyctes) coeculus (Brölemann, 1889) is new to Russia. One more species appears to be new to Asian Russia: Lithobius (Lithobius) lucifugus L. Koch, 1862. The record of L. (L.) melanops Newport, 1845 is new to Siberia. Three species, (L. (M.) crassipes C.L. Koch, 1862, L. (L.) forficatus (Linnaeus, 1758) and Lamyctes (Lamyctes) emarginatus (Newport, 1844)), are formally recorded in southwestern Siberia for the first time.

ACKNOWLEDGEMENTS. We are most grateful to Dr. S.I. Golovatch (Moscow, Russia) who kindly checked the English. We are also thankful to Dr. A.I. Shmakov (Barnaul, Russia), Director of the South Siberian Botanical Garden and to Dr. V.I. Usenko (Barnaul, Russia), Director of the M.A. Lisavenko Research Institute for Horticulture of Siberia, who allowed us to collect material inside and outside hothouses of their institutions. We are thankful to $\mathrm{Yu}$.V. Dyachkov for his help with distribution maps. Our deepest gratitude extends to all collectors who donated us their material for the present study.

\section{References}

Barber A.D. 2011. An indoor record of Lithobius melanops Newport, 1845 from the Falkland Islands // Bulletin of the British Myriapod \& Isopod Group. Vol.25. P.46-47.

Bonato L., Chagas Junior A., Edgecombe G.D., Lewis J.G.E., Minelli A., Pereira L.A., Shelley R.M., Stoev P., Zapparoli M. 2016. ChiloBase 2.0 - A World Catalogue of Centipedes (Chilopoda). Available at http://chilobase.biologia.unipd.it (accessed 15 June 2016)

Bukhkalo S.P., Sergeeva E.V. 2012. [Interannual dynamics of composition and structure of soil invertebrate communities in the root terrace of the Irtysh] // Belgorod State University Scientific Bulletin. Natural sciences. No.15(134). Issue 20. P.59-64 [in Russian].

Cupul-Magaña F.G. 2011. Nueva distribución de Lamyctes coeculus (Brölemann, 1889) (Chilopoda: Lithobiomorpha: Henicopidae) en México // Acta Zoologica Mexicana (nueva serie). Vol.27. No.1. P.197-200.

Cupul-Magaña F.G. 2013. Primer registro del ciempiés introducido Lamyctes emarginatus (Newport, 1844) (Lithobiomorpha: Henicopidae) para México // Entomotropica. Vol.28. No.1. P.6164.

Dvořák L., Dvořáková K. 2015. [Some invertebrates recorded in subterraneae spaces of the Dyleňský kras] // Dyleňský kras. Mariánské Lázně: Městské muzeum Mariánské Lázně. P.145156 [in Czech].

Eason E.H. 1976. The type specimens and identity of the Siberian species described in the genus Lithobius by Anton Stuxberg in 1876 (Chilopoda: Lithobiomorpha) // Zoological Journal of the Linnean Society. No.58. P.98-127.

Eason E.H. 1977. On Lithobius melanops Newport (Chilopoda: Lithobiomorpha) in North America // Entomological Monthly Magazine. Vol.112. P.65-66.

Eason E.H. 1996. Lithobiomorpha from Sakhalin Island, the Kamchatka Peninsula and the Kurile Islands (Chilopoda) // Arthropoda Selecta. Vol.5. No.3/4. P.117-123.

Edgecombe G.D. 2004. Remylamyctes (Chilopoda: Lithobiomorpha), a henicopid centipede from Madagascar and Réunion // Zootaxa. Vol.686. No.1. P.1-11.
Edgecombe G.D., Giribet G. 2003. A new blind Lamyctes (Chilopoda: Lithobiomorpha) from Tasmania with an analysis of molecular sequence data for the Lamyctes-Henicops Group // Zootaxa. No.152. P.1-23.

Enghoff H. 1975. Notes on Lamyctes coeculus (Brölemann), a cosmopolitic, parthenogenetic centipede (Chilopoda: Henicopidae) // Entomologica Scandinavica. Vol.6. No.1. P.45-46.

Farzalieva G.Sh. 2008. [The fauna and chorology of Myriapoda from the Urals and Cisuralia]. PhD Thesis. Perm State University. 189 p. [in Russian].

Gerstfeldt G. 1858. Ueber einige zum Theil neue Arten Platoden, Anneliden, Myriapoden und Crustaceen Sibiriens, namentlich seines östlichen Theiles und des Amur-Gebiets // Mémoires L'Académie Impériale des Sciences. St. Petersbourg. T.8. S.136.

Haase E. 1880. Zur Kenntnis der sibirischen Myriapoden // Zoologischer Anzeiger. Bd.3. No.55. S.223-225.

Korobushkin D.I., Semenyuk I.I., Tuf I.H. 2016. An annotated checklist of the Chilopoda and Diplopoda (Myriapoda) of the Abrau Peninsula, northwestern Caucasus, Russia // Biodiversity Data Journal. No.4:e7308. P.1-33.

Lewis J.G.E. 1985. Centipedes entering houses with particular reference to Geophilus carpophagus Leach // Entomologist's Monthly Magazine. Vol.121. P.257-259.

Minoranskij V.A. 1977. [Some data on Chilopoda (Myriapoda) from the Rostov Region] // Vestnik zoologii. No.4. P.38-43 [in Russian].

Nefediev P.S. 2001. [On the fauna and ecology of Myriapoda in the environs of the village of Smolenskoe, Altai Province] // Landshafty Zapadnoj Sibiri: problemy issledovanij, ekologiya i ratsionalnoe ispolzovanie. Materialy VII Mezhdunarodnoi mezhvuzovskoi konferentsii, posvyaschyonnoi Dnyu Zemli. Biysk: Biysk Pedagogical State University Publ. P.84-86 [in Russian].

Poloczek A., Pfeiffer M., Schneider R., Müchlenberg M. 2016. The Chilopoda (Myriapoda) of the Khentey-Mountain Range, Northern Mongolia. Communities of different forest-types under a varying fire regime // European Journal of Soil Biology. Vol.74. P.114-120.

Rybalov L.B. 2002. [Zonal and landscape changes in soil invertebrate populations in a near-Yenisei River region of Middle Siberia and the role of temperature adaptations in the meridional (zonal) distribution of invertebrates] // Russian Entomological Journal. Vol.11. No.1. P.77-86 [in Russian, with English summary].

Sergeeva E.V. 2013. [Biotopic distribution and number of centipedes (Chilopoda) in Irtysh valley of West Siberia, Russia] // Euroasian Entomological Journal. Vol.12. No.6. P.529-533 [in Russian, with English summary].

Silvestri F. 1909. Contribuzioni alla conoscenza dei Chilopoda, III. Descrizione di alcuni generi e specie di Henicopidae // Bollettino del Laboratorio di Zoologia Generale e Agraria, Portici. Vol.4. No.1. P.38-50.

Striganova B.R., Poryadina N.M. 2005. [Soil animal population in boreal forests of West-Siberian Plain]. Moscow: KMK Scientific Press Ltd. 234 p. [in Russian].

Stuxberg A. 1876. Myriopoder från Sibirien och Waigatsch ön samlade under Nordenskiöldska expeditionen 1875 // Öfversigt af Kongl. Vetenskaps-Akademiens Förhandlingar. Årg.33. No.2. S.11-38.

Sseliwanoff A.W. 1880. Eine Bemerkung über "Lithobius sibiricus" Gerstfeldt's // Zoologischer Anzeiger. Bd.3. No.68. P.541543.

Sseliwanoff A.W. 1881. Neue Lithobiiden aus Sibirien und Central-Asien // Zoologischer Anzeiger. Bd.4. No.73. P.15-17.

Tuf I.H., Ivinskis P., Rimšaite J. 2015. A check-list of the centipedes (Chilopoda) of Lithuania // Zootaxa. Vol.4052. No.3. P.394-400.

Tuf I.H., Kopecký O., Mikula J. in press. Can montane and cave centipedes inhabit soil? // Turkish Journal of Zoology. DOI: 10.3906/zoo-1508-34.

Tuf I.H., Laška V. 2005. Present knowledge on centipedes in the Czech Republic - a zoogeographic analysis and bibliography 
1820 - 2003 // K. Voigtländer (ed). Myriapoda in Europe. Habitat and biodiversity. Peckiana. Vol.4. P.143-161.

Volkova Yu.S. 2014a. [The fauna of predatory myriapods of the Simbirsk Volga Region] // Priroda Simbirskogo Povolzhiya. Sbornik nauchnykh trudov XVI mezhregionalnoj nauchno-prakticheskoy konferentsii "Estestvennonauchnye issledovaniya v Simbirskom-Ulyanovskov krae". Vol.15. P.95-103 [in Russian].

Volkova Yu.S. 2014b. [Preliminary review of the Myriapoda fauna of the Saratov Area] // Entomologicheskie i parazitologicheskie issledovaniya v Povolzhie. Sbornik nauchnykh trudov. Vol.11. P.149-151 [in Russian].

Vorobiova I.G. 1999. [Ecological and faunistic characteristics of myriapod populations in the mid-flow region of Yenisei River] // Problemy pochvennoi zoologii. Materialy II (XII) Vserossiyskogo soveschaniya po pochvennoi zoologii. Moscow: KMK Press. P.33-34 [in Russian].

Vorobiova I.G., Rybalov L.B., Rossolimo T.E., Zalesskaja N.T. 2002. [Zonal and landscape distribution of the myriapod fauna and populations (Myriapoda) in the Yenisei River basin] // Izuchenie, sokhranenie i vosstanovlenie bioraznoobraziya ekosistem na Yeniseiskom ekologicheskom transekte: Zhivotnyi mir, etno-ekologicheskie issledovaniya, 2. Moscow: IPEE RAN Publ. P.60-71 [in Russian].
Zalesskaja N.T. 1978. [Identification book of the lithobiomorph centipedes of the USSR]. Moscow: Nauka Publ. 212 p. [in Russian].

Zapparoli M. 2003. The present knowledge on the distribution of the European fauna of Lithobiomorpha (Chilopoda) // Bulletin of the British Myriapod and Isopod Group. Vol.19. P.20-41.

Zapparoli M. 2009. An annotated catalogue of the epigeic and cave centipedes (Chilopoda) of Sardinia // P. Cerretti, F. Mason, A. Minelli, G. Nardi, D. Whitmore (eds.). Research on the Terrestrial Arthropods of Sardinia (Italy). Zootaxa. Vol.2318. P.56168.

Zapparoli M. 2011. New records and remarks on the centipede fauna of endogean habitats of Sardinia (Chilopoda) // G. Nardi, D. Whitmore, M. Bardiani, D. Birtele, F. Mason, L. Spada, P. Cerretti (eds.). Biodiversity of Marganai and Montimannu (Sardinia). Research in the framework of the ICP Forests network. Conservazione Habitat Invertebrati. No.5. P.223-242.

Zapparoli M. 2013. Fauna Europaea: Lithobiomorpha // H. Enghoff (ed.). Fauna Europaea: Myriapoda, version 2.6.2. Available online at http://www.faunaeur.org (accessed 15 June 2016).

Zuev R.V. 2016. Centipedes (Chilopoda) from the Stavropol Territory, northern Caucasus, Russia // Arthropoda Selecta. Vol.25. No.1. P.23-38.

Responsible editor S.I. Golovatch 